\title{
A Glass Half Full: The Growing Strength of French Political Science
}

\author{
Andy Smith \\ Centre Emile Durkheim
}

Paper given at the Congress of l'Association française de science politique, Bordeaux, $2^{\text {nd }}$ July, 2019

It is hard to remain positive at a time when our discipline is experiencing a considerable reduction in new jobs, when far too many of our young doctors are struggling to get by on temporary and futureless contracts, the physical conditions within many of our organizations are deteriorating due to budgetary cuts and the differences in resources between them are increasing (Déloye \& Mayer, 2018). Nevertheless, despite all these serious issues and the pressing need to address them with policy and political changes, it is important to recall and underline some of the key qualities of contemporary political science in France, and indeed the strengthening it has undergone over the last three decades. This exercise is valuable not only to remind ourselves, and others wishing to understand and susceptible to supporting us, just how far we have come over the past 50 years. It is crucial if we, as a discipline, are to continue to believe in what we do and how it contributes to the production and dissemination of knowledge within the social sciences, but also considerably beyond it.

For these reasons, this paper successively presents three sets of data and analysis which are all harnessed to argue that today's political science in France has considerable strength, i.e. a solid base from which it is more than conceivable that its scientific and societal impacts can further increase in the future. In this country, the discipline's first strength is its institutionalization as a profession, a phenomenon which goes hand in hand with a capacity to generate robust, and most often collective, research projects, data and results. Secondly, the data I mobilize shows that although the internationalization of French political science does not necessarily take the shape of publishing in English and, in any case remains uneven, it has nevertheless significantly increased over the last two decades. Thirdly and finally, unlike some other national equivalents, this professionalization and internationalization has not been paralleled by a clear-cut separation between our science and the rest of the society. On the contrary, as section 3 will show, whilst publishing increasingly in refereed journals and publishing houses, many members of the French political science community have continued to contribute to public debates in a variety of ways.

Of course, when one claims a glass is half full, this means that the other half is empty. Our disciplinary acquis and our current assets cannot and must not blind us to the deep challenges that lie before us at the national scale, but also at that of regions, universities, departments and research centres. Nevertheless, by negotiating 'from strength' we stand a much better chance of shaping these issues as problems in the ways we ourselves define them, 'owning them', then proposing concrete solutions, as well as convincing influential outsiders to rally to our cause. As we know from research conducted in our own discipline, 
positive self-talk and self-presentation can be performative. It is high time we applied this lesson to ourselves ${ }^{1}$.

\section{Professionalization: Reorganisations and Systematizations}

Although there are still only around 560 tenured political scientists working in France today ${ }^{2}$, the profession has not only grown considerably since the 1990s, but has also been paralleled by a significant rise in student numbers and research output. More fundamentally still, in addition to the figures on these points that are interpreted successively below, it is important to stress the extent to which the institutions (i.e. rules, norms and conventions) which structure the governance of our profession have stabilized and progressively been made more transparent. It follows that contrary to what certain colleagues fear, 'professionalization' does not necessarily signify 'a standardisation of analytical perspectives', or even 'the loss of academic freedom'. Rather, to paraphrase Dubar, Tripier and Boussard (2015: 13), I use this term to capture how political science has become a stabilized 'professional group', i.e. one that is recognized as such both by its members and by its most significant interlocutors (notably the Ministry of Education, the CNRS and each University).

\section{Jobs and recruitment procedures}

As various histories of the political science in France have rightly highlighted (Favre, 1989; Darras \& Philippe, 2014; Gaïti and Scot, 2017), the autonomization of French political science began to institutionalize in the 1980s thanks largely to the creation of a recruitment path for professors in political science that was separate from law -le concours d'agrégation ('I'agreg'), together with a growing commitment by the CNRS to recruit political scientists and provide career paths for them (beginning slowly in the 1970s). Over the course of that decade and the 1980s, a national community of political scientists progressively grew in size and became increasingly coherent. The dilettantes interested in 'political studies' began to be marginalized then replaced by a more distinct professional identity and set of norms. One indicator of this trend is the organization of the country's first national political science congresses organized by the AFSP in Paris $\left(1981^{3}\right)$, Grenoble (1986) and Bordeaux (1988). Another is the emergence of new journals within, or very close to, the discipline - notably Politix in 1988 and Genèses in 1991. More significant growth took place during the 1990s up until the mid-2000s. During this period, a growth rate of $3.3 \%$ in the number of permanent positions for political scientists was maintained between 1986 and 1996, tailing off to 2.8\% for the period 1996-2006. (Déloye, 2012). In short, retrospectively the 1990s and early 2000s

\footnotetext{
${ }^{1}$ Although wherever possible what follows is based upon 'objectified' data, its interpretation is obviously coloured by my own trajectory. It is therefore important to clarify that my experience of French political science began with a masters (1991) then a PhD (1995) at the Institut d'études politiques de Grenoble. My first and only tenured post has been as a research fellow at the Fondation Nationale des Sciences Politiques, based at Sciences Po Bordeaux (1996 >). I should also add that I was director of the Centre Emile Durkeim from 2013 to 2016 and, since the autumn of 2016, have both chaired the Association française de science politique and been a member of the CNRS's committee that covers Political science (and part of sociology: la Section 40). As regards this paper, I would like to thank Jean Joana, Thibaut Joltreau and Christophe Roux for their valuable assistance. Of course, responsibility for its content and any possible errors remains entirely my own.

${ }^{2}$ This figure compares unfavourably with most other Western democracies. Both Germany and the UK each feature around 2000 tenured political scientists, but Italy only 200 (Roux, 2014). Meanwhile, in 2010 the USA had around 9300 (APSA, 2011).

${ }^{3}$ And this more than thirty years after the founding of the AFSP in 1949.
} 
was la belle époque for French political science, one during which many of its organizations grew and its institutions began to stabilize. In particular, the AFSP's congress became a regular, two-yearly national event. Like the 'real' belle époque, however, that of French political science only lasted around fifteen years. Since then, job creation has slowed and even fallen during some years, frequently creating gaps in teaching capacity ${ }^{4}$.

Nevertheless, the figure of around 560 tenured academics in France who are identified as, and/or identity themselves as, political scientists is made up of approximately 240 lecturers (maîtres de conférences) and 130 professors employed by the Ministry for Higher Education and Research ${ }^{5}$, about 120 full-time researchers who work for the CNRS, 40 from the Fondation nationale des sciences politiques and around 40 other colleagues who work for a variety of other employers (e.g. IRSTEA, AgroParisTech, I'Université Catholique de Lille). Many of these posts are located in Paris and its surrounding region. This said, the geographical fragmentation of our discipline should also be noted. As Yves Déloye underlines (2017: 6), in 2013 there were political science posts in no less than 67 French public higher education establishments. However, 35 of these were in organizations where there were 3 or less political scientists and 18 where there were between 4 and 8 . More fundamentally still, he has identified elsewhere that in 2012 for every post of professor or lecturer in political science, in law there were 21 (Déloye, 2012, p. 112). To borrow a term from the health sector, in France political science is 'a rare' discipline and has been recognized as such by the Ministry of Higher Education and Research ${ }^{6}$.

These figures are disturbing and, indeed, threaten to weaken our discipline in this country. At the same time, it is important to underline that recruitment procedures have undergone significant reforms which have made the way we evaluate candidates who enter the profession more equitable and transparent than ever before. Here it is important to recall that until the 2000s this was a serious problem which sapped the very credibility of our profession. In the case of lecturer jobs, until the recent changes many universities and IEPs clearly favoured either 'local' candidates (i.e. those who had completed their PhDs within their walls), or those who shared the same theoretical standpoint that predominated locally. Although such forms of bias have not been completely eradicated, legislation, the norms of our profession and the vigilance of many of its candidates have attenuated them considerably. This has taken the form of ratios of external selection committee members (at least half), ratios of women on these boards (again at least half), rules regarding conflicts of interests (no member of the committee can have supervised the thesis of a candidate who interviewed). Moreover, generally, these interviews are considerably longer than hitherto (but still much shorter than in countries like the US or the UK).

\footnotetext{
${ }^{4}$ This gap has regularly been patched over by the intensive use in universities of PhD candidates and post-docs without a position to fill in holes in the capacity to actually provide the increased number of teaching hours entailed by this change. France has some institutionalised non-permanent positions at the graduate level (called contrat doctoral, funded by the national government, and which can encompass a fixed number of teaching hours per year (a maximum of 64 hours). Secondly, temporary teaching jobs ('ATER'), are taken up either by $\mathrm{PhD}$ candidates nearing completion or those who have recently finished their doctorate. These jobs take the form of contract for up to 2 years (as a rule; in some exceptional cases it can be extended up to 4 years), and this for a 96-hour teaching workload per year - I think it is 128 hours for full-time contracts as for a MCF or a PR). But a large portion of this work is in fact paid through hourly contracts ('vacataires'), all of which creates a situation of great 'precariousness'. See today's article in Times Higher Education.

${ }^{5}$ This data is that of the Ministry itself: https://data.enseignementsup-recherche.gouv.fr

${ }^{6}$ Fabienne BLAISE, Pierre MutZenHARDt, Gilles Roussel, Sibylle RochAs, Disciplines rares. Rapport à Madame la Secrétaire d'Etat à l'Enseignement Supérieur et à la Recherche auprès de la Ministre de l'Education Nationale, de l'Enseignement Supérieur et de la Recherche, Paris, Ministère de l'Enseignement Supérieur et de la Recherche, 16th December 2014
} 
Similar developments have occurred within the committees which participate in recruiting CNRS researchers. Again, clearer rules have been introduced over conflicts of interests (e.g. no committee member who has worked with a candidate can speak in meetings when they are discussed). Moreover, today much fewer candidates are actually interviewed than prior to 2016, thereby generating more time for longer interviews and analysis of their projects and publications. More fundamentally, over the 2010s the criteria around which each application is evaluated have been made clearer and placed more firmly at the centre of decision-making.

In summary, this section has sketched out the development of French political science by focusing in particular upon the quantity of political scientists who have become members of this profession, then by presenting some of the rules, norms and conventions (institutions) which now structure their recruitment. Let me stress once again that today this quantity is insufficient and that these institutions still need improving and further stabilization. Nevertheless, with these elements squarely in mind, the focus of this paper can now switch to where, and under what conditions, those recruited teach and conduct their research.

\section{Teaching degrees and student numbers}

What is first important to explain to outsiders to our profession, be they foreign or indeed French, is the difference between the two types of 'site' within which political science is taught in this country: universities ('les fac') and Institut d'études politiques (IEPs, often called Sciences Pos). The former, are mostly parts of law faculties (or ones of law and political science). In contrast, as part of a singular national system of higher education called 'grandes écoles', IEPs benefit from more resources per student. However, given that their diploma also encompasses courses in law and economics, the quantity of teaching in political science IEP students actually receive is variable and often quite low.

From the point of view of our discipline, the majority of lecturers and professors teach in the 17 French universities which offer degrees within which political science plays a role of varying magnitude. Traditionally, at the equivalent of BA level this teaching has taken place within joint degrees with other disciplines - above all law, but also history and economics. However, a number of BAs specialized in political science alone have been created over the past few years. Today there are 15 of these degrees ${ }^{7}$.

Table 1: Numbers of students taking degrees in political science within French universities

\begin{tabular}{|c|c|c|c|c|c|c|}
\hline \multirow{3}{*}{$\begin{array}{l}\text { Level } \\
\text { Period }\end{array}$} & \multicolumn{2}{|c|}{$\begin{array}{l}\text { Number of higher education institutions } \\
\text { where PS is taught }\end{array}$} & \multicolumn{4}{|c|}{ Number of students enrolled } \\
\hline & BA level & MA level & \multicolumn{2}{|c|}{ BA level } & \multicolumn{2}{|l|}{ MA level } \\
\hline & 2017 & 2017 & $2012-3$ & $2016-7$ & $2012-3$ & 2016-7 \\
\hline $\begin{array}{l}\text { Courses where } \\
\text { Political Science is } \\
\text { dominant }\end{array}$ & 17 & 103 & $\begin{array}{l}3,726 \text { in } \\
(0.4 \% \text { of } \\
\text { all BA } \\
\text { students })\end{array}$ & $\begin{array}{l}9.409 \text { in } \\
(0.9 \% \text { of } \\
\text { all BA } \\
\text { students })\end{array}$ & $\begin{array}{l}22,513 \text { in } \\
(2.7 \% \text { of } \\
\text { all MA } \\
\text { students })\end{array}$ & $\begin{array}{l}19,854 \text { ? in } \\
\text { (3.0\% of all } \\
\text { MA } \\
\text { students) }\end{array}$ \\
\hline
\end{tabular}

Source: Roux (2019) based on data of the French ministry of Higher Education (DGSIP).

\footnotetext{
${ }^{7}$ These are at the universities of Paris 1, 2, 8, VIII, Paris-Nanterre, Paris-Est Créteil, Paris-Est Marne la Vallée, Versailles-Saint Quentin, Lille, Picardie, Rennes 1, Lyon 2, des Antilles, Mulhouse and Montpellier in 2019.
} 
Meanwhile, although they are also part of universities (and would be labelled as such in most other countries), approximately 100 of the 370 teaching positions in French political science are located in the ten Institut d'études politiques of this country. These entities are distinctive firstly because access to them has always been restricted by an exam-based entry procedure (concours) - a form of selection which, until a governmental reform introduced in 2017 (Parcoursup), Universities were not allowed to practice.

Table 2: Numbers of students studying within Institut d'études politiques

\begin{tabular}{|l|c|}
\hline & Number of BA \& MA students \\
\hline Paris & 7000 \\
\hline Strasbourg & 1200 \\
\hline Bordeaux & 2000 \\
\hline Grenoble & 1200 \\
\hline Toulouse & 1250 \\
\hline Lyon & 1200 \\
\hline Aix-en-Provence & 1150 \\
\hline Lille & 1000 \\
\hline Rennes 1300 & 1070 \\
\hline Saint-Germain-en-Laye & 600 \\
\hline
\end{tabular}

Source: Approximate figures drawn from the websites of each IEP (accessed $4^{\text {th }}$-7th June 2019)

Then there is the specific case of Sciences Po Paris. Although this is only one organization, it is a particularly large one that, above all, is highly central to the discipline of political science in France, and this because between 10 to $15 \%$ of the positions of professors and researchers are located there ${ }^{8}$. Sciences Po occupies a specific position also because of changes in the recruitment strategy it has implemented over the past few years. Its status as a private foundation has always made it possible to employ not only professors from the public service, but also to hire researchers and now professors on the basis of private sector contracts. Since the mid-2000s, this has led not only to an autonomous policy in terms of increasing the number of positions opened over the years, but also to launching a shift away from the French academic market and towards one that is European, if not 'global'. This shift has also been possible thanks to more flexibility over the pay scales linked to these private positions.

Despite their important differences, when one takes IEPs and universities together, one sees that expansion of political science has taken place at BA level (a particularly important point in the French case), and even more so at that of MAs. Meanwhile, the number of PhDs completed has increased during the 2010s, but at a slower rate than during the preceding decade. In total, just over 3,000 doctoral dissertations have been completed in political science in France since the mid-1980s (Roux: 2019). Moreover, what is important to stress here is that the slow growth of the last decade or so can no longer be attributed to a rise in the number of grants for PhDs attributed by the national ministry for research. These are still in place but have rarely increased in number since the 2000s. Instead, what has grown are the number of PhDs funded as part of grants for collective research projects (notably

\footnotetext{
${ }^{8}$ If we add to these figures the number of permanent teaching and research positions held on a private sector status (and not that of a civil servant), Sciences Po has about 90 permanent positions in political science.
} 
those accorded by the Agence Nationale de la Recherche (ANR) and certain Regional Councils, such as that of Nouvelle Aquitaine and Brittany).

Table 4: Number of PhD dissertations defended in political science

\begin{tabular}{|c|c|c|}
\hline $\mathbf{1 9 4 9 - 8 9}$ & $\mathbf{2 0 0 0 - 2 0 0 9}$ & $\mathbf{2 0 1 0 - 2 0 1 8}$ \\
\hline c. 1000 & 950 & 1047 \\
\hline
\end{tabular}

Source: Roux (2019: 12) based on data from the Agence bibliographique de l'enseignement supérieur (ABES).

As for the previous sub-section on jobs in political science, it is important to supplement quantitative analysis with some more qualitative points regarding the rules, norms and conventions that have come to structure how our discipline is taught in France. The first thing to underline here is that in this country there is generalized resistance to the standardization of a political science curriculum, and this in the name of 'defending academic freedom'. Some efforts have been made at the national scale to set out a 'threshold' range of subject matter that ought to be covered in a BA, for example. Meanwhile, some IEPs in particular have focused more upon the 'skills' their students are expected to develop. However, rightly or wrongly, in themselves these moves have not caused significant change in the structuring of teaching in our discipline in this country.

What has had greater effects has been the systematization of organizational evaluation within all of French higher education and research. Whereas previously evaluation had barely been formalized at all in this sector, in 2006 the French Ministry of Education and Research created its first evaluation agency: l'Agence pour l'évaluation de la recherche et l'enseignement supérieur: AERES (which in 2012 was renamed the Haut Comité pour l'évaluation de la recherché et l'enseignement supérieur: I'HCERES). As regards teaching, every five years this organization 'evaluates' each teaching establishment by examining its respective curricula and pedagogical projects. Here the term evaluation is no doubt excessive given that these exercises are generally relatively superficial and barely concerned with assessments of impact, if at all. Nevertheless, as bureaucratic rules and requirements, they have imposed a cycle of reflection and report preparation upon each teaching organization, thereby rendering moments when change can be introduced more obvious, and in many cases more deliberative.

In summary, over the past twenty years, the structuring and quantity of teaching of political science has changed considerably. Understandably, many colleagues have experienced this trend negatively as 'bureaucratization' and, more prosaically, as simply an increase in their workloads. Nevertheless, from the point of the discipline this trend has also contributed, often painfully but surely, to the discipline's strengthening.

\section{The systematization of research and the scientific method}

As I have just mentioned, the HCERES has also systematized the evaluation of research in France. Although, and unfortunately for this paper, the mode of evaluation adopted has not generated systematic data on research projects and publications in political science, it is important once again to briefly set out its wider impact on the discipline. From there other less comprehensive but nevertheless informative - data can then be presented in order to 
support my argument that in the domain of research too, French political science has strengthened over the past two decades.

As regards the evaluation of research conducted by the HCERES using teams of colleagues from our discipline and those close to it (essentially Sociology), it is important to stress that individual researchers are not assessed directly by this organization. Evaluations of the work of each individual are carried out to some extent by the CNRS, the FNSP and the Conseil National des Universities (through its section 04). Instead, the main French mode of research evaluation targets the centres within which this activity takes place. As regards our discipline, there are currently around twenty such centres within which a significant number of political scientists work. These centres range in size from c.100 tenured staff (all disciplines included) to between 10 and 15 (not to mention other research centres which include a minority of political scientists). What is important to retain here is that, for each centre, every five years the HCERES essentially examines five issues: its amount and rate of publications, its structuring in terms of research priorities and groups, its relationship to doctoral supervision, its administrative support and the project it has set itself for the future. The central aim of this mode of evaluation is therefore to address issues of collective action. The production of research is nevertheless examined to a certain extent. Indeed, there is some evidence to suggest that the HCERES's evaluations, together with new norms for grant applications etc., have indirectly acted as incentives to modify the publication strategies of many political scientists in France (e.g. exhortations to publish more articles than book chapters, and this particularly in English). Welcomed by some political scientists as a tool for encouraging 'increased rigour', rejected by others as 'bureaucratic interference in academic liberties', this mode of evaluation is nevertheless now a stabilized part of being a political scientist in France.

In terms of outcomes, one can at least conclude with greater certainty, as Fabien Jobard did a decade ago, that today's political scientists publish regularly. Table 3 synthesizes data from the reports produced for the HCERES over 2015-18 by 8 research centres where many political scientists work ( 3 located in Paris and 5 elsewhere, 5 attached to an IEP and 3 to a ' $f a c '$ ').

Table 3: Publications in eight French research centres over a five-year period in the mid-2000s

\begin{tabular}{|l|r|r|}
\hline & Total production & $\begin{array}{l}\text { Average production by } \\
\text { head (N =423) }\end{array}$ \\
\hline Peer reviewed articles & 1692 & 4.00 \\
\hline Authored books & 328 & 0.78 \\
\hline Edited books & 539 & 1.27 \\
\hline Book chapters & 2088 & 4.94 \\
\hline
\end{tabular}

Source: the reports prepared for the HCERES by eight centres collated by Joana et. al. (2018).

Of course, the amount of material published constitutes only one of the many outputs of colleagues in our discipline. It would, for example, be interesting to generate knowledge on all the collective research projects that have been completed in these same centres during this period. From this perspective, what I can only present instead is data on all the research contracts obtained by political science in France from the national research agency: l'Agence nationale de la recherche (ANR). Created in 2005-7, this source of funding is significant because whereas previously research in political science in France had most often been financed through relatively small programmes (notably via the CNRS and individual 
ministries), since then most national funding has been channelled through the ANR. Each year a series of calls for projects are published, the projects received are evaluated, then funding decisions are taken and published ${ }^{9}$. Using several sources which include but also extend beyond the ANR itself ${ }^{10}$, I found that between 2005 and 2017 a total of 59 projects were funded that involve political scientists heavily ${ }^{11}$ - i.e. an average of 5 new projects a year. In budgetary terms, these projects received a total of 10,141,522 euros of ANR funding, i.e. an average of 171,890 euros per project (Smith, 2019).

To contextualize this rate of funding, and thus of 'success', the ANR itself claims to have financed a total of 380 social science and humanities projects over this same period ${ }^{12}$. If one takes this figure seriously, this means that political science has managed to be at the centre of $15 \%$ of them - a rate many from our discipline would consider insufficient, but which, when one takes into account our size in France, is no doubt comparable, or indeed better than, our neighbours in say sociology. Nevertheless, the rate of funding for our discipline as a whole is only 845,127 euros per year. And it is not much consolation to know that for 2005-2014, the ANR's SHS budget as a whole was only 26 million euros out of a total of 589 million, i.e. just $4.5 \%$ of the total budget ${ }^{13}$. Although direct comparisons are difficult, the ANR's budget for the SHS is far less than that of the British Economic and Social Resarch Council. For example, the latter's total budget for 2017-18 was $£ 202$ million $^{14}$.

Moreover, particularly since an internal reform in 2014 that re-empowered bureaucrats from the Ministry of Research, the ANR's criteria for funding have become even less political science-friendly. Indeed, the challenge for our discipline here has been that ANR fund has increasingly been restricted to projects that are interdisciplinary (where possible entailing co-operation with the bio-chemical sciences) and/or which clearly show how they will be of use to practitioners in the worlds of business and administration. When one adds that the overall budget of the ANR has been repeatedly cut, needless to say political science is increasingly rarely being funded by it. Although, fortunately, other sources of funding still exist (notably from some Conseils Régionaux and for Universities who have attracted IDEX funding from the state, as well as EU research funds ${ }^{15}$ ), the scope for financing 'fundamental' and disciplinary-specific research in French political science remains low.

\footnotetext{
${ }^{9}$ This agency has a number of specialized instruments (e.g. for Franco-German projects) but most of the money for which political scientists are eligible comes from a 'generic fund' (le programme blanc).

${ }^{10}$ Our sources here include a document published by the ANT in 2018 (L'action publique au prisme de la recherche en sciences humaines et sociales. Bilan des projets financés depuis 2005 par l'ANR), information on the ANR's websites: http://www.agence-nationale-recherche.fr/suivi-bilan/rechercher-un-projet-finance and the triangulation of both with information provided directly to me by our discipline's main research centres.

${ }^{11}$ Political scientists are also involved in many ANR projects dominated by other disciplines, however this involvement is very difficult to assess, let alone quantify.

${ }^{12}$ ANR, L'action publique au prisme de la recherche en SHS, op. cit., 2018, p. 7.

${ }^{13}$ ATHENA, ANR, analyse de son budget SHS 2005-2014, avril 2015, p. 4.

${ }^{14}$ ESRC, The Effect of ESRC. An Analysis of the Inputs and Outputs of the Economic and Social Research Council's Research Funding Process, October 2017. Disponible à https://esrc.ukri.org/about-us/performance-information/.

${ }^{15}$ Funding at the EU level has only had a moderate impact upon political science in France. Although the EU's framework programmes have involved a number of French political scientists over the years, this involvement has rarely been from a position of leadership. Moreover, ERC grants are rarely accorded to colleagues working in this country. Both these trends are linked to application levels that are probably lower than in other member states. But in turn, and more fundamentally, this low application rate can be largely explained by there being a general perception amongst French colleagues that EU funding is biased towards more positivist and quantitative political science than that that which predominates in France.
} 
Despite all this evidence that funding research in political science in contemporary France is far from easy, the point I wish to underline is that so many of our colleagues still manage to finance and conduct their respective projects. Indeed, whilst arguing that our funding environment should be otherwise and working towards that goal, it is vital to underline that this resilience to conduct research 'despite it all' provides further evidence of the institutionalized strength of our discipline.

\section{Internationalization: a deepening of individual and collective practices}

My second set of reasons for considering that French political science has strengthened over the past two decades concerns the degree to which the practices of its academics have 'internationalized' during this period. This claim will seem surprising, and even outlandish, to many non-French and French colleagues. The former tend strongly to consider that French political science remains insular and cut-off from the rest of the world's political science. At the very least, they are surprised that our discipline in France 'punches below its weight'. Meanwhile, the latter often confuse internationalization with a standardization of world political science which they either vigorously applaud or, alternatively, reject outright in the name of epistemological pluralism and academic freedom. The difficulty here is that both these views on the one hand conflate internationalization with publishing in elite, and even elitist, English language journals whilst, on the other, producing no actual data to back up their respective claims. This is why in 2017-18 the AFSP commissioned a report from five of its members (Joana et. al, 2018), a report which in particular first clarified a more meaningful and robust definition of internationalization then, on this basis, generated quantitative and qualitative data in order to reassess the current state of French political science in this regard.

As regards defining internationalization, the report stressed that in addition to publishing in a language other than French (and in particular in English), internationalization encompassed other important issues including:

- The recruitment of tenured staff;

- The generation of empirical data in countries other than France;

- The engagement of researchers and their publications in scientific debates which extended beyond national frontiers (via 'states of the art' and bibliographical referencing, but also networks).

The analytical conclusion the Joana report drew from this definitional exercise, and one I have adopted below, is that the best way of actually studying the internationalization of French political sciences is to examine the actual practices relevant to each of these three dimensions of internationalization.

\section{Recruitment patterns and the variety of countries studied}

As regards that of recruitment, at first glance French political science does indeed appear to have a problem with internationalization. Of the 123 persons recruited to tenured positions in the discipline between 2013 and 2017, only 7 had PhDs that had been obtained abroad, and only 7 others had been funded jointly by a French and a foreign university (what is 
known in French as cotutelle). These figures are indeed low, and would no doubt remain so even if one took into account PhDs which had been co-supervised by a colleague from another country (codirection) ${ }^{16}$. However, it is important to underline that no less than 40 of those recruited, i.e. one third, had completed a post-doc overseas before being recruited. Moreover, given that being able to teach and exchange with colleagues in French is still considered in France to be a necessity for tenured staff, is this low ratio of foreign-trained 'recruitees' so surprising? Should one not be seeking to understand instead why French nationals who, for a variety of reasons, completed their PhDs overseas, often have great difficulty in either being recruited as lecturers in France, or returning home later in their careers as professors or CNRS Directeurs de recherche? In both cases, explanation needs to dig deeper than simply to affirm that French political science is 'insular' ${ }^{17}$.

As regards the generation of data on studying foreign countries at the PhD level, at least at the level of entry to the profession, French political science actually does rather well. Of the 123 entrants who make up the population defined above, the PhDs of only 45 of them had been centred on France alone, whilst 72 of them at least engaged in comparative analysis and/or were entirely devoted to foreign polities.

This feature of political science practice in France can also be examined by looking at the subject matter of journals and books. Here the data that exists concerns the countries that have featured in France's longest standing political science journal, the Revue française de science politique (RFSP) ${ }^{18}$. Drawn from Thibault Boncourt's PhD. dissertation, this data highlights that between 1973 and 2007, no less than 53\% of articles published in the RFSP were centred upon France, 19\% on the rest of Europe, $5 \%$ on the USA and $16 \%$ on the rest of the world (Boncourt, 2011: 236) ${ }^{19}$. However, in updated figures which Boncourt himself helped compile (Joana et. al, 2018), RFSP articles focused solely on France were down to only 31\% for the period 2014-2017 - a proportion which no doubt compares favourably with many American and British journals. Moreover, the subject matter of book reviews published in the RFSP has also been assessed. This exercise finds that since 2010 an average of 230 are reviewed each year, and on average $35 \%$ of the books concerned were published in a language other than French (and nearly all in English) (Joana et. al., 2018). Finally, the Joana report also compiled a list of the references cited in all the articles published in the RFSP between 2014 and 2017. It found that a total of 5631 references were made, of which $46 \%$ were in French, $48 \%$ in English and $6 \%$ in other languages.

\footnotetext{
${ }^{16}$ Significantly, as Roux underlines (2019: 9), in political science it is still rare for a PhD in France to be written in a language other than French. According to ABES's data, out of around 3,000 doctoral dissertation undertaken in political science in a French university since the mid-1980s, approximately 100 were written in another language (c. 80 in English, 8 in German, 6 in Spanish, 3 in Italian, 2 in Portuguese, 2 in Romanian, 1 in Czech, 1 in Russian, 1 in Japanese).

${ }^{17}$ In the case of French nationals seeking to return to France as lecturers, a key point of explanation lies in differing conceptions of the format a PhD should take (in France they are typically much longer than in the rest of Europe and the US) and the expectation that at least part of its research results should be published in French journals. As regards, appointments to the CNRS at Directeur de recherche level, any such recruitment automatically has the compensatory consequence of cutting one entry-level job the following year.

${ }^{18}$ To our knowledge, little systematic data exists on the centrality of the RFSP. However, Fabien Jobard (2010) has shown that for the 130 CNRS political scientists, no less than $9 \%$ of their articles were published there in the period 2004-8.

${ }^{19}$ For the corresponding period, Boncourt also shows that $45 \%$ of articles published in Political Studies were centred upon the United Kingdom (2011: 236).
} 
Of course, this type of counting exercise has its limits, as does limiting the dataset to the RFSP. Nevertheless, at the very least it does provide further evidence of the non-insularity of much of today's French political science.

\section{Publications and Engagement in extra-National Debates}

Indeed, to bolster this claim it is no doubt more heuristic to focus more closely upon how political scientists actually engage with knowledge produced abroad within their publications and projects. To my knowledge, two relevant datasets exist which help tackle this question. To this I add new material regarding the publications and projects of candidates to the CNRS in 2016-7.

The first dataset of interest to us here was compiled by Emiliano Grossman (2010) on the basis of a questionnaire-based survey he conducted with tenured political scientists in France in 2009 regarding their respective publication strategies. Amongst the findings drawn from the 243 responses received, Grossman highlights first that the journals French political scientists prefer to submit to are virtually all French. Secondly, however, he shows that many of them read international journals, notably International Organization, West European Politics and the Journal of European Public Policy. Third, he suggests strongly that the key variable which determines whether a French political scientist seeks to publish in the highest ranked international journals is whether they use quantitative methods or not. In conclusion, Grossman tentatively proposes an analysis of the publications strategies of French political scientists as falling into one of three types: 1) a set of around 100 colleagues who publish only in French (and who mostly see themselves as in 'political sociology'; 2) a smaller set (c. 50) of colleagues who are highly engaged in international publication; and 3) a large but disparate grouping of colleagues (c. 250) whose strategies of publication appear to have no consistent logic (other than perhaps a tendency to publish in sector-specialized journals).

This data has been updated and extended by the Joana report (2018). Specifically, when analysing the publications of the eight research centres mentioned in section 1 , it produced the figures set out below in table 4. Their analysis highlights firstly that the percentage of articles in a foreign language in peer-reviewed journals oscillates between 22 and $32 \%$ for most of the research centres studied, is as high as $78 \%$ for one centre and $52 \%$ for another, but falls to $11 \%$ for one outlying centre. Even including the latter, these figures are much higher than most colleagues from both outside and within France would expect them to be. Not surprisingly given the linguistic effort needed, the number of authored books published in a foreign language is considerably lower. But rates of publishing in English in particular rise once more the moment one examines books and special issues that colleagues in France have edited, or the chapters they have published in such volumes. It is certainly no accident that rates are higher in centres attached to an IEP where, generally, there is more funding available for translations, foreign language editing and, indeed, travel to foreign conferences. Nevertheless, overall this data strongly suggests that for many French colleagues publishing in English in particular is now a stabilized, even routine, part of their respective practices. 
Table 4: The proportion of publications in foreign languages in 8 French research centres

\begin{tabular}{|c|c|c|c|c|c|c|c|c|}
\hline & L. 1 & L. 2 & L. 3 & L. 4 & L. 5 & L. 6 & L. 7 & L. 8 \\
\hline \multicolumn{9}{|l|}{ Articles in PRJs } \\
\hline \multicolumn{9}{|l|}{ Published in } \\
\hline another language & 29 & 77.7 & 23.9 & 11.4 & 51.7 & 21.5 & 30.5 & 31.9 \\
\hline of which English (\%) & 29 & 75.9 & 21.3 & 7 & 47 & 18.6 & 26.9 & 25 \\
\hline of which other (\%) & (0) & $(1.8)$ & $(2.6)$ & $(4.4)$ & (4.7) & (2.9) & (3.6) & (6.9) \\
\hline \multicolumn{9}{|l|}{ Authored books } \\
\hline in English (\%) & 10 & 44.4 & 6.4 & 2.3 & 24.7 & 15 & 6,1 & 5 \\
\hline Other (\%) & (0) & $(22.2)$ & $(3.2)$ & (9.5) & (7.6) & (7.5) & $(12.2)$ & (15) \\
\hline \multicolumn{9}{|l|}{ Book chapters } \\
\hline In English (\%) & 35.4 & 59 & 16.5 & 8.3 & 32.7 & 17.9 & 22.5 & 17.8 \\
\hline other (\%) & $(2.5)$ & (1.6) & $(2.3)$ & $(4.4)$ & (4.8) & (5.5) & (6.1) & (3.1) \\
\hline \multicolumn{9}{|l|}{$\begin{array}{l}\text { Edited books or } \\
\text { special issues }\end{array}$} \\
\hline in English (\%) & 23.9 & 54.5 & 8.9 & 2 & 27.6 & 19.8 & 25.7 & 13.3 \\
\hline other (\%) & (0) & (0) & (0) & (0) & $(6,7)$ & $(6,3)$ & $(1,4)$ & (0) \\
\hline \multicolumn{9}{|l|}{ Environment } \\
\hline & FAC & IEP & IEP & FAC & IEP & IEP & IEP & FAC \\
\hline Localisation & Paris & Paris & Prov. & Prov. & Paris & Prov. & Prov. & Prov. \\
\hline
\end{tabular}

Source: Joana et. al. (2018) on the basis of these centre's reports to the HCERES over 2015-8.

$\mathrm{PRJ}=$ Peer reviewed journals.

Finally, a third set of data I myself produced allows us to focus upon the practices of younger political scientists, specifically those who in 2017 sought to be recruited to the CNRS. Here the focus was narrowed to the 41 candidates that the commission 40 selected for interview. Material taken from these applications has been analysed here in two ways.

Firstly, I examined the publications list of each candidate in order to ascertain the quantity of publications produced, their type and, in the case of articles, the journals applicants had been successful in targeting. The aim here was to first obtain an overall picture of publishing practices, then to see whether any pattern of normed behaviour emerged from this data. Our principal findings set out in table 5 were that virtually all applicants had already published a great deal (on average a book, an edited book or special issue, 6 articles and 5 book chapters).

Table 5: Total number of publications by the 41 CNRS candidates interviewed by the Section 40 in 2017

\begin{tabular}{|c|c|c|c|c|}
\hline Authored Books & Edited Books & Spec. issues edited & PRJ articles & Book Chapters \\
\hline 42 & 16 & 21 & 240 & 202 \\
\hline
\end{tabular}

Source: author's own calculations from candidate's publication lists

These publications featured a relatively high average number of journal articles per applicant (5.9), but also a relatively low number of journal articles published in English (46, i.e. just over one per applicant on average). As regards the broader patterns that emerge from this data taken as a whole, they appear firstly to confirm that books, edited books and book chapters are still given considerable importance by the best evaluated applicants to the CNRS. Indeed, the weight of institutionalized priorities as regards books still appears to be firmly in place. Moreover, this trait seems logically to have some bearing upon the relatively low importance accorded by these candidates to publishing in English-language journals. But 
here perhaps the difficulty of doing so, particularly at the beginning of one's career, is probably more telling.

The second set of data I compiled concerned the bibliographical references listed in the research projects of these 41 applicants. Although simply counting these references does not tell us whether they were really used to construct the project, nor whether the applicant was in agreement or in disagreement with those they cited, what they do provide is an overall indication of how these applicants have positioned themselves within a literature that is either essentially global, global and French or essentially French. The average number of publications cited per applicant was 122 (with a range from 44 to 402). 51\% of all references were in French, 48\% in English and 1\% in other languages. On average, each applicant's project contained 59 references in English. Of the 41 candidates examined, there was only one essentially 'global'-type applicant for whom English references constituted more than $80 \%$ of their bibliography. Similarly, there were also only two essentially Frenchtype applicants for whom references in French accounted for more than $80 \%$ of their references. Instead, 38 of the applicants found themselves within the broad category which now dominates French political science identified by Grossman (2010) - i.e. they used both French and non-French references.

In summary, over the past twenty years in particular, French political science has clearly experienced an internationalization of its practices. Indeed, as Joana et al. (2018) conclude, 'this internationalisation is probably not as weak as it is often said to be'. If some of the trends outlined above could, of course, be further encouraged, the overall result is positive and promising.

\section{In the City: sustained engagement beyond academia}

Beyond teaching, the conducting of research and publishing its results, there are of course many other ways political scientists throughout the world have engaged with the polities within which they live and work. Indeed, as our funding bodies increasingly emphasize, 'having impact' upon society is now part of the normative framework within which our discipline operates. Rather than pursue the tortuous and contested path of 'impact' per se, what I seek to underline instead here is not only that French political science has engaged with 'the city' for decades, but also that a large number of the current members of our profession are particularly active on this front. Once again, systematic data on this point could be collated and analysed if the HCERES, or indeed the CNRS, were to provide access to their relevant evaluation reports. Unfortunately, these organizations have thus far failed to do so. For this reason, for example, it is impossible to list all the expertise political scientists have contributed to ministries, NGOs and more general public debates in the recent past. Similarly, no systematic data exists as regards the number of blogs and other forms of internet discussion to which members of our profession contribute. What I have chosen to highlight instead is, on the one hand, the extent to which colleagues publish books in formats likely to attract readers from beyond the social sciences then, on the other, some new data on those who have published 'op ed.' pieces in leading national newspapers.

As regards the first point, I simply wish to briefly describe a trait of French political science which is not necessarily shared by members of our discipline in all other countries: the 
willingness of many of our colleagues to publish books designed for a public that both includes other social scientists and members of a wider public. Known as vulgarisation in French, this practice stems in part from the continued existence of publishers keen to play their part in it. For example, the publishers Raisons d'agir, Editions du croquant and parts of Les Presses de Sciences Po's output all fit in this category (see Box 1$)^{20}$.

Box 1: Examples of recent essays (also) aimed at a non-specialist public by French political scientists

Raisons d'agir:

G. Gourgues \& Neushwander C., Pourquoi ont-ils tué LIP? De la victoire ouvrière au tournant néo-libéral, 2018

Boelaert J., Michon S., Ollion E., Métier: député. Enquête sur la professionnalisation de la politique en France, 2017

Lefebvre R., Les primaires socialistes, la fin du parti militant, 2011

Presses de Sciences po:

L. Rouban, Le paradoxe du macronisme, 2018

S. Gensberger \& S. Lefranc, A quoi servent les politiques de mémoire?, 2017

E. Grossman, N. Sauger, Pourquoi détestons-nous autant nos politiques?, 2017

B. Gazier, B. Palier, H. Périvier, Refroidir le système de la protection sociale, 2014

D. Battistella, Un monde unidimensionnel, 2013

Editions du Croquant:

C. Georgieu, Les grandes firmes françaises et l'Union européenne, 2019

O.Ihl, La barricade renversée. Histoire d'une photographie, Paris 1848, 2016

P. Aldrin, L. Bargel, N. Bué, C. Pina, Politiques de l'alternance, 2016

Of course, part of the reason political scientists in France choose to publish in this way is linked to the limited opportunities they now have to publish orthodox research books in 'university' presses. As the latter become increasingly reluctant to publish books that they consider are unlikely to sell well, not surprisingly many colleagues feel they have been 'forced' to turn to other publishing houses. Judging by the content of the books produced in this format, however, just as many actually prefer to publish in this vein as a means of communicating their research results to a wider audience. Although other members of our profession are sometimes critical that this type of publication occurs at the expense of publishing in refereed journals and publishing houses, the debate, such as it exists, over this point has thus far remained unstructured. Moreover, it has yet to generate any concrete and feasible alternatives.

The second way I have chosen to examine how French political science currently engages with 'the City' is to produce new data on its engagement with national newspapers. Political scientists throughout the world have always contributed to public debates in this way. Again, as for the type of books sketched out above, many colleagues are critical of this form of engagement. Some see the format of a newspaper article as simply too short for presenting genuine research results, whereas others are more concerned about the normativity, and sometimes even the narcissism, they consider motivates such publications.

Putting aside these important issues, it nevertheless remains important to grasp the actual practice of newspaper publishing amongst the current cohort of 563 political scientists working in France. This I did in the second half of May 2019 by cross-checking a list of all

\footnotetext{
${ }^{20}$ To this should be added a range of journals that also cater for the non-specialized public (e.g. Savoir-Agir).
} 
these colleagues with the Europresse database. More precisely, I limited my search to three national newspapers generally accepted as reflecting a reasonably representative crosssection of the political spectrum (Libération, Le Monde and Le Figaro). Despite some colleagues targeting other national papers (e.g. La Tribune or La Croix), important regional dailies (e.g. Ouest France) or indeed newspapers published in the countries that they study (e.g. The Indian Times), this choice was made because, despite all the changes in the field of the media over the last twenty years (Neveu, 2009), the three newspapers chosen continue not only to be national and generalist, but also to impact upon the French press as a whole (Benson, 2017: chapter 2). Another methodological choice made was to focus only upon 'op. eds.', i.e. articles published in these newspapers where the political scientist-author(s) had a clearly identifiable byline (thereby excluding cases where colleagues have been interviewed by a journalist - another interesting practice that merits analysis but which could not be done in this instance). Despite all these limitations, this exercise has produced the following two sets of initial results.

The first has been simply to quantify the number of articles published by our cohort: 1405 . As Figure 1 sets out graphically, Le Monde is clearly the newspaper most of the authors concerned have sought to publish in, but this ratio could also perhaps be explained by the paper being more open to 'opinion' pieces by members of our discipline, or perhaps is by its reputation for being at the centre-left of the political spectrum. One could also reasonably speculate that the reason so many colleagues have published articles in Libération is that this newspaper is reputedly 'on the left', a positioning many of them also share. But seen from this angle what is more surprising is the number of political scientists who have published in Le Figaro - a paper that is clearly identified with the political right.

In any event, an obvious weakness of my research on this point is that it produces no data on the number of articles that were submitted to each paper and not accepted for publication. In addition, it does not separate out pieces that were actually commissioned by each newspaper, as opposed to simply submitted by the political scientist in the hopes that it might be published. Finally, at this stage it is not possible to say whether the rate of publication has increased or not over time. Indeed, although most of the articles concerned date from the last two decades, given the differing length in the careers of the population concerned, rigorous analysis over time would have to include colleagues who are now retired in the database.

Similarly, it makes little sense to give importance to the average number of articles published per current political scientist (2.5). What is, however, more interesting is to note the wide range in the quantity of publications identified: between 0 and 95 per political scientist. Indeed, when one digs a little deeper one discovers that 201 of today's political scientists have published in these papers, and 362 have not (Figure 2). There is therefore a distinct difference between either/or:

- those who consider that publishing in such papers is a legitimate part of their role as a political scientist vs. those who do not;

- colleagues who do not consider themselves sufficiently or legitimate to publish in these newspapers vs. those who do. 
Figure 1: Repartition of articles published by today's French political scientists in 3 newspapers

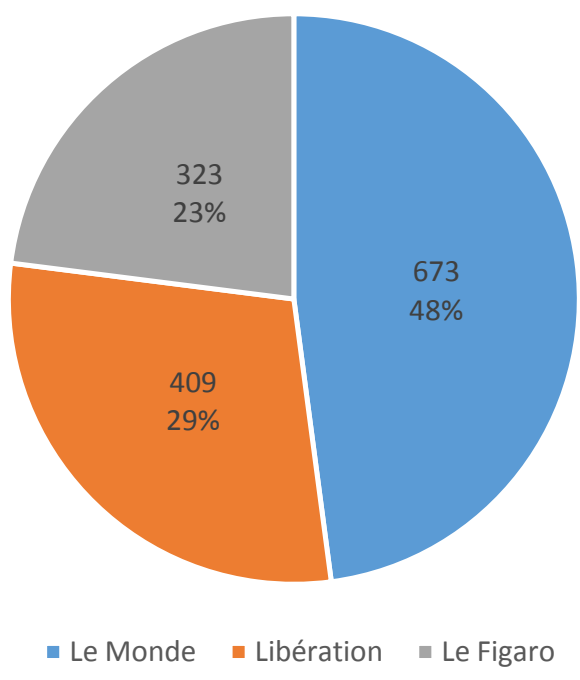

Figure 2: The ratio of today's French political scientists who have published in these three newspapers

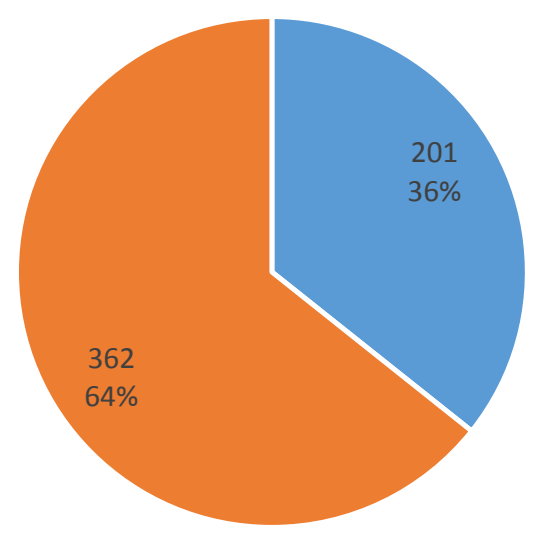

- Have published - Have not published

There is clearly much more that could and should be researched and said about how contemporary political scientists engage with 'the City', and this as regards France and more generally $^{21}$. What is presented here is little more than a beginning. Nevertheless, it does firmly indicate that in this country our discipline does a great deal to involve itself in public debates and, in so doing, distance itself from the stigma of 'the ivory tower' which, in France as elsewhere, we so often still have to deal and live with.

\footnotetext{
${ }^{21}$ In the US, APSA commissioned a report on this subject (APSA, 2014). Surprisingly, however, it contains very little detail about actual practice in that country. Instead, the report is essentially a plan of action on 'how to do better' (including how APSA could help to do so).
} 


\section{Conclusion: Reasons to be Cheerful ${ }^{22}$}

As I underlined from the outset of this piece, concerning political science in France, there is of course a great deal that could and should be improved upon. As individual and collective participants in this science, we could all no doubt do (even) better. More pertinently, the environment within which we operate needs to be much more conducive to the production of high quality teaching and research. For example, there is no doubt more jobs, clearer and more equitable recruitment and promotion procedures, greater funding for fundamental research and the emergence of more publishers open to its production would all be highly beneficial to our discipline and profession in this country. Difficulties of each of these issues provides part of the explanation why most political scientists in France currently appear to be rather pessimistic about their discipline. More generally, its small size compared to that of other countries, but above all the growing gap between workloads and resources, together with the bureaucratization of procedures in a context of seemingly incessant reform, have all contributed to an ambiance filled with tensions and suspicions.

Nevertheless, it is also important to recall both how far we have come in the last halfcentury and what has already been achieved. During this period, political science in France has emancipated itself from law, professionalized its recruitment, teaching and research practices and internationalized all three of them, at least to some extent. Meanwhile, unlike in some other national instances, all this has been accomplished without cutting off our discipline from the rest of social science nor, more importantly still, from public debate. Colleagues from within and without the discipline will no doubt disagree with a number of the interpretations and conclusions made throughout this text. Indeed, their discussion and critique is more than welcome and highly necessary for us all to make further progress and obtain the support from outside the discipline that we so dearly need. But let this discussion take place while raising a glass that is half full - one that encourages us to work towards filling it to the brim, rather than bemoaning the fact that so much of our 'glass' currently remains so empty.

\section{References}

APSA (American Political Science Association) (2011) Political Science in the $21^{\text {st }}$ Century, https://www.apsanet.org/21stcentury

APSA (American Political Science Association) (2014) Improving Public Perceptions of Political Science's Value, Task Force Report. https://www.apsanet.org/publicperceptions.

Benson R. (2017) L'immigration au prisme des medias. Une comparaison France-Etats-Unis, Rennes: Presses Universitaires de Rennes.

Boncourt T. (2011) L'internationalisation de la science politique: une comparaison franco-britannique, PhD dissertation, Sciences Po Bordeaux.

Darras, E., Philippe, O. dir. (2004), La science politique une et multiple, Paris, L'Harmattan.

\footnotetext{
${ }^{22}$ For inspiration listen to 'Reasons to be cheerful part 3', lan Dury and the Blockheads, 1979.
} 
Déloye, Y. (2012), 'Eléments pour une morphologie des politistes français au vingt et unième siècle. Note de recherche', Politique \& Sociétés, 31 (3): 109-126.

Déloye, Y. (2017) 'La revolution silencieuse de la science politique française', forthcoming in E. Darras, ed.

Déloye, Y., Mayer, N. (2008), ‘French Political Science at a Turning Point', French Politics, 6 (6): 280-301.

Déloye, Y., Mayer, N. (2019), 'Les trois défis de la science politique française: retour sur la period 1968-2018', Idées économiques et sociales, issue 195: 28-39.

Dubar C., P. Tripier \& V. Boussard (2015) Sociologie des professions, Paris: Armand Colin.

Favre, P. (1989), Naissances de la science politique en France (1870-1914), Paris: Fayard.

Gaïti B., Scot M. (2017) 'Une sciences sans savants? Les paradoxes de l'émergence de la science politique en France entre 1945 and 1968', Revue française de science politique, 67(1): 13-42.

Grossman, E. (2010), 'Les stratégies de publication des politistes français', Revue française de science politique, 60 (3): 565-585.

Joana J., Boncourt T., Dutoya V., Holeindre J-V., Mayer N. (2018) Quelle internationalization pour la science politique française?, report commissioned by the Association française de science politique (https://www.afsp.info/quelle-internationalisation-pour-la-science-politique-francaise/).

Jobard, F. (2010), 'Combien publient les politistes ? La productivité des politistes du CNRS et leurs supports de publication', Revue française de science politique, 60 (1), p. 117-132.

Mazur A., Elgie R., Grossman E. (eds.) (2017) Oxford Handbook of French Political Science, Oxford, Oxford University Press.

Neveu E. (2009) Sociologie du journalisme, Paris: La Découverte

Roux C. (2014) 'Forty years of political science in Italy: A few comments on a happy birthday', Italian Politics \& Society, 74, Spring, pp. 53-65.

Roux C. (2019) Report on the state of political science (in France), unpublished report.

Smith A. (2019) 'L'impact de l'ANR sur la recherché en science politique', internal note prepared for the Association française de science politique. 